\section{Human Trafficking in Peru: Stakeholder Perceptions}

\author{
Julie Anne Laser-Maira MSW, LCSW, PhD (Corresponding author) \\ Graduate School of Social Work, University of Denver \\ 248 High St, Denver, CO, United States
}

Tel: 1-303-803-6323Ｅ-mail: julieannelaser@gmail.com

\author{
Christopher Scott Huey; MS \\ Monitoring and Evaluation Specialist, Chemonics International, Inc \\ Washington DC, United States \\ E-mail: chuey@chemonics.com \\ Orion Antonio Laser Castro \\ Researcher, Metro State University of Denver \\ Denver, CO, United States \\ E-mail: orion.122448@gmail.com \\ Kathryn Hope Ehrlich \\ Researcher, Light and Leadership Initiative, Peru \\ Lima, Peru \\ E-mail: ie@lightandleadership.org
}

Received: December 18, 2015 Accepted: February 1, 2016 Published: February 2, 2016 doi:10.5296/ijsw.v3i1.8750 URL: http://dx.doi.org/10.5296/ijsw.v3i1.8750

\begin{abstract}
Peru has been found to be a country of destination, origin, and transit of men, women, and children subjected to forced labor and sex trafficking. Peruvian news highlights growing
\end{abstract}


trends in labor and sex trafficking, but it is widely recognized that there is a paucity of rigorous data on the subject.

This study interviewed stakeholders involved in prevention, intervention, and support of victims of human trafficking in Peru. The research team surveyed thirty human trafficking organizations throughout Peru. Questions included where victims come from, gender, age, how they are trafficked, who trafficks them, where they are trafficked to, how traffickers maintain control, whether they were trafficked for the purposes of sex or labor, duration of trafficking, and how they were able to exit their exploitation. Additionally, each organization was asked from their vantage point, what they would do to end human trafficking in Peru.

The findings from this research add substantially to the knowledge of the clandestine world of human trafficking. This research is one of the first studies in Peru that gives insight into both the extent of the problem of human trafficking and real solutions of how it can be combatted.

Keywords: Peru, Human trafficking, Trafficking in Persons, Sex trafficking, Labor trafficking, Slavery, Exploitation stakeholders

\section{Introduction}

Despite slavery being illegal in every country in the world, estimates suggest there are more people trafficked for the purposes of slavery today than ever before in history (Free the Slaves, 2015). Though the figures vary wildly due to insufficient data, the U.S. Department of Health and Human Services (HHS) approximates the number between 12 and 27 million people worldwide (HHS, 2015). The act of slavery has not changed since its inception, but the institution itself has seen dramatic changes with modernity, proving itself able not only to survive, but to thrive within the oft-hidden informal markets of a globalized society rife with increasing levels of poverty and vulnerability. As more attention is shifted towards the problem, it is increasingly apparent that human trafficking and slavery are daunting problems for even the most developed nations of the world.

No longer hindered by the regulation and public criticism of legality, this new form of the sale, transfer, and receipt of human beings, known today as human trafficking or trafficking in persons (TIP), entraps people through infinitely varied forms of force, fraud, and/or coercion. Due to it's clandestine nature, human trafficking has proved itself to be incredibly difficult to identify, research, and combat, yet only shows signs of gaining momentum. According to the United Nations (UN), TIP generates 32-36 billion dollars in profit annually, third only to drug and arms trafficking (UN, 2014), and shows no signs of slowing. Indeed, the relatively low risk, cost, and ease of TIP, when compared to drug and arms trafficking (Haynes, 2004) would suggest this illicit industry will continue rapid growth for the foreseeable future.

Peru is no stranger to trafficking and slavery. When the Spanish first arrived in Northern Peru under the command of Francisco Pizarro in 1528 they exploited the native population by breaking up families and transporting individuals for the purposes of forced labor, rape, and domestic servitude (Stern, 2004). By the 1580s the Spanish had largely abandoned indigenous enslavement in favor of importing African slaves, whom came with less restrictions by the Spanish government on their use (Bowser, 1974). Slavery was officially abolished in Peru in 1854 but the practice has continued to survive through the indiscriminate 
trafficking of vulnerable populations regardless of race, age, or gender - especially within industries often hidden from public view, such as mining, logging, drug production, and war-making (CHS, 2010).

There is no doubt that Peru's human trafficking and slavery problem continues today. The U.S. State Department's (DOS) Trafficking in Persons Report, which began tracking worldwide statistics in 2005, has found Peru to be a country of destination, origin, and transit country for men, women, and children subjected to forced labor and sex trafficking (DOS, 2014). Every year, regional and national news highlight growing trends in labor and sex trafficking all over the country (El Comercio, 2015). The rise of the guerilla military insurgency known as the Shining Path in the 1980s, for example, saw an introduction of the forced recruitment and use of child soldiers, a practice that continues today (UNICEF, 2012). The situation is exacerbated by reports by human rights advocates of nearly non-existent resources, services, and legal protections for increasingly vulnerable populations (CHS, 2013).

Anecdotal reports provide evidence of regional variations of trafficking in Peru. In the mountain Quechua-speaking regions, such as Cusco, it is not uncommon for modern traffickers to trick parents into parting with children by taking advantage of the historical but now defunct "padrino system", whereby wealthy land owners or distant wealthy relatives would offer to shelter, feed, and educate the child of a poverty-stricken family in exchange for that child's domestic labor (DOS, 2014). In the Amazonian city of Iquitos, in the Department of Loreto, Posters and signs in Spanish demand "no child sex", demonstrating to tourists the extent of the problem and their desire to eradicate the problem. In other jungle regions, often far removed from State control, such as Madre de Dios, there are reports and evidence of children forced to work in gold mines and children forced to work in brothels to cater to the miners (Zevallos, interview, June 11, 2014). Peru's capitol, Lima, is exemplary of an industrialized modern city along the Pan-American highway and yet still struggles with forced begging, prostitution, and drug trafficking. With a population of approximately 30.1 million and a poverty rate at $30 \%$ (more than $55 \%$ in rural areas) (CIA, 2015) it is not surprising that human trafficking is thriving throughout the country. In its 2014 Report, the Walk Free Foundation's (WFF) Global Slavery Index estimates approximately 66,300 people to currently be living in slavery in Peru, ranking it $4^{\text {th }}$ in South America for the prevalence of modern slavery (WFF, 2015).

\section{Review of Literature}

It is widely recognized that there is a paucity of empirically rigorous data concerning human trafficking. Difficulties of conducting research on human trafficking are many, not the least of which include limited availability of resources and the difficulties involved with interviewing victims (Bennan, 2005). Human trafficking is a clandestine crime and few victims and survivors come forward for fear of retaliation, shame, or lack of understanding of what has happened to them (DOS, 2014). The result is a dearth of research studies on human trafficking in Peru. Most studies that have been published rely on statistical estimates and anecdotal evidence.

Despite these challenges, Peru presents a unique opportunity for obtaining rare and reliable data on the patterns of human trafficking and slavery. Because Peru, apart from some isolated 
areas, is not a conflict zone, the relatively reasonable mobility and safety is a boon to effective fieldwork. Peru is also primed for change as public awareness of the multiple forms of trafficking in the three geographically distinct regions of the country: coast, mountain, and jungle, receive increased public interest and awareness. The national government has begun mobilizing state and local resources, nearly doubling the Ministry of Interior's budget for prevention activities from approximately $\$ 142,000$ in 2013 to approximately $\$ 355,400$ for 2014 (DOS, 2014). With the subsequent creation of the 2011-2016 National Plan of Action Against The Trafficking of Persons and increased nonprofit outreach, it is more important than ever to conduct empirical research in Peru and provide the tangible data necessary to combat human trafficking and help support its survivors recover from trauma.

Currently, the most reliable research in Peru has been undertaken by a few local non-profit and non-governmental organizations. However, they work with limited resources and typically have a narrow focus on the sexual exploitation of women and children at the expense of neglecting other forms of trafficking. There are few, if any, peer-reviewed articles and the Government of Peru rarely allocates state resources and attention to research. What statistics the government does provide on human trafficking are generally agreed upon by the anti-trafficking community in Peru to be unreliable. In its 2014, Trafficking in Persons Report, the U.S. State Department noted the "government data on victim identification and law enforcement efforts was unreliable, making it difficult to assess these efforts" (DOS, 2014, 311).

Some of the most reliable and comprehensive research has been produced by the Peruvian nonprofit Capital Humano y Social Alternativo (CHS), which has published over 33 regional reports covering a wide variety of topics, from documenting law enforcement trends and analyzing state initiatives to measuring public awareness and tracking human trafficking routes. The most unique and possibly impactful of these studies are two on the perceptions of human trafficking by Peruvians and a map of domestic trafficking routes based on cases reported by law enforcement through a now defunct system set up by CHS, known as RETA (CHS RETA, 2012). The founder and Executive Director of CHS, Ricardo Valdés Cavassa, has confirmed that collecting data is not an exact science; while the recorded numbers of reported cases have risen each year, Valdés is aware of hundreds more cases that are not formally reported. Human trafficking is a lot bigger than the numbers would suggest but unless law enforcement, service providers, and citizens themselves are all working cooperatively, the data will continue to fail to reflect the reality and seriousness of the problem (Valdez Cavassa, interview, 2012).

Another Peruvian nonprofit, El Centro de Promoción y Defensa de los Derechos Sexuales y Reproductivos (PROMSEX), has published a number of reports designed to increase public awareness of the trafficking of women and children throughout the country. One recent study (2014) supported by PROMSEX highlighted the health outcomes of adolescent victims who had been trafficked to the illegal gold mining operations in the Department of Madre de Dios (Mujica). This study was the first of its kind and emphasized the dire need for more investigations into the growing labor and sex trafficking operations to isolated mines throughout Peru (Mujica, 2014). The remaining studies on the subject of human trafficking are produced by external Non-Governmental Organizations, such as the International 
Organization for Migration (IOM), and often reference Peru in the context of regional Latin American reports, as opposed to it being the main focus of study.

Thus the goal of this research is to contribute to the current body of knowledge of human trafficking in Peru by filling a need for peer-reviewed research on patterns of trafficking. This research investigated the methods used to entrap victims, the methods used by traffickers to exert and maintain control over victims, the demographics of those being trafficked, the occupations in which the victims worked, and the duration of exploitation.

\section{Methodology}

\subsection{Sample}

The population that was studied is the stakeholders that work with victims of human trafficking in Peru. These individuals have a great deal of knowledge of the experiences of the trafficked individuals, but most have not personally experienced being trafficked thus reducing the risk of participation in the study. The bilingual research team, which consisted of the designers and investigators of this study, first interviewed the most prominent non-profits, NGOs, and governmental organizations working to end human trafficking throughout four regions of Peru (Lima, Cusco, Iquitos, and Puerto Maldonado). Additional organizations were located through referral from the original list of those surveyed, culminating in a total of 30 . At each organization we interviewed direct service workers, administrators and when available, organizational founders. The 30 human trafficking organizations surveyed were involved in all aspects of human trafficking prevention, intervention, and support, which included: mental health, health care, law enforcement, community advocacy and outreach, shelter, education and vocational skills, research and evaluation, referral, food assistance, employment services and legal services.

\subsection{Data Collection Procedures}

Six month prior to administering surveys in the field, we began arranging interviews with the most prominent organizations working to end human trafficking in Peru. Once in the field, the research team met individuals in person to discuss the research project. Most were very eager to participate in the research.

Data collection occurred throughout the summer of 2014. Informed consent was first obtained in Spanish, and then the surveys were completed in Spanish. Often the surveys generated a lot of discussion and further questions and ideas. We visited four different Departments of Peru known to have significant human trafficking issues: Lima, Cusco, Madre de Dios, and Loreto.

\subsection{Instrumentation}

\subsubsection{Human Exploitation in Peru Instrument (HEPI)}

The HEPI is a 78-question survey that was filled out at every Human Trafficking Organizations by knowledgeable stakeholders. It was created by the researchers and then sent to Peru in Spanish to clarify meaning and validity. It was first piloted with a few organizations in Peru and then used in this research. The survey asked specifically about where victims come from, gender, age, how they are trafficked, who trafficks them, where they are trafficked to, how traffickers maintain control over them, whether they were trafficked for the purposes of sex or labor, the average duration of trafficking, and how they are able to exit their exploitation. 


\section{Results}

The thirty organizations that were visited worked in eight locations: Cusco, Puerto Maldonado, Lima, Iquitos, Tumbes, Puno, Trujillo and Apurimac. Some organizations worked in many areas of Peru, others in only one area. The organizations had 0 to 400 paid workers, and 0 to 20 volunteer workers.

The services provided by these organizations were: mental health $(30 \%)$, law enforcement (36.7\%), community advocacy and outreach (56.7\%), shelter (23.3\%), education or vocational education $(33.3 \%)$, investigations/evaluations $(33.3 \%)$, referrals $(30 \%)$, food assistance (26.7\%), employment services (10\%), and legal services (43.3\%). The duration of service to victims varied from one day to over seven years per victim.

Some of the organizations collaborated formally with other anti-trafficking organizations on anti-trafficking events and projects $(75.9 \%)$ others did not $(24.1 \%)$. Some organizations shared information informally with other anti-trafficking organizations $(79.3 \%)$ and others $\operatorname{did} \operatorname{not}(20.7 \%)$.

The organizations believed that victims of human trafficking came from diverse areas in Peru. They named twenty different areas/cities where they knew victims were originally from: Iquitos, Puerto Maldonado, Cusco, Lima, Tumbes, Trujillo, Puno, La Libertad, Ica, Lambayeque, Chilayo, Ucayli, Abancay, Arequipa, Tacna, Piura, Huancayo, San Martin, Jaen, and Apurimac. A third of the organizations also believed that some victims of human trafficking in Peru originated from outside of Peru.

A variety of transport was used to move victims of human trafficking. Most frequently used modes of transportation were planes $(65.5 \%)$, busses $(58.6 \%)$, boats $(58.6 \%)$, cars $(56 \%)$, combis (vans) (34.5\%), and donkeys (3.4\%).

When asked how traffickers gained access to victims, there were a wide variety of methods used to deceive, recruit and entrap victims.

Table 1. How traffickers gained access to victims

\begin{tabular}{|c|c|c|}
\hline Method used to entrap victims & $\begin{array}{l}\text { Organization had heard } \\
\text { method being used }\end{array}$ & $\begin{array}{l}\text { Method was often used } \\
\text { to entrap victims }\end{array}$ \\
\hline Recruiter enticed victim & $96.6 \%$ & $41.4 \%$ \\
\hline Victim experienced extreme poverty & $96.6 \%$ & $48.3 \%$ \\
\hline False offers of work were given & $93.10 \%$ & $51.7 \%$ \\
\hline Victim was a run away & $89.7 \%$ & $13.8 \%$ \\
\hline Victim was escaping domestic violence & $86.2 \%$ & $17.2 \%$ \\
\hline Victim was abandoned by family & $82.8 \%$ & $24.1 \%$ \\
\hline $\begin{array}{l}\text { False Padrinos(pretended to be distant relative } \\
\text { of family to obtain victim) }\end{array}$ & $79.3 \%$ & $24.1 \%$ \\
\hline Online offers of work were given & $75.9 \%$ & $6.9 \%$ \\
\hline
\end{tabular}


Parents sold victim

Victim was escaping sexual abuse

Recruiter offered parents a better life for $72.4 \%$ victim

Chaperones told parents that they would $72.4 \%$ provide transport to victim

Pimp enticed victim

$69 \%$

$69 \%$

$65.5 \%$

$65.5 \%$

$58.6 \%$

$51.7 \%$

$51.7 \%$

$44.8 \%$

$44.8 \%$

$17.2 \%$

Victim was escaping parent's substance abuse
$3.4 \%$

$24.1 \%$

$10.3 \%$

$17.2 \%$

$24.1 \%$

$10.3 \%$

$37.9 \%$

$10.3 \%$

$10.3 \%$

$6.9 \%$

$10.3 \%$

$6.9 \%$

$10.3 \%$

$10.30 \%$

Traffickers were able to exert and maintain control over victims in a variety of ways.

Table 2. How traffickers were able to exert and maintain control over victims

\begin{tabular}{|c|c|c|}
\hline Method used to entrap victims & $\begin{array}{l}\text { Organization had heard } \\
\text { method being used }\end{array}$ & $\begin{array}{l}\text { Method was often used } \\
\text { to entrap victims }\end{array}$ \\
\hline Recruiter enticed victim & $96.6 \%$ & $41.4 \%$ \\
\hline Victim experienced extreme poverty & $96.6 \%$ & $48.3 \%$ \\
\hline False offers of work were given & $93.10 \%$ & $51.7 \%$ \\
\hline Victim was a run away & $89.7 \%$ & $13.8 \%$ \\
\hline Victim was escaping domestic violence & $86.2 \%$ & $17.2 \%$ \\
\hline Victim was abandoned by family & $82.8 \%$ & $24.1 \%$ \\
\hline $\begin{array}{l}\text { False Padrinos (pretended to be distant } \\
\text { relative of family to obtain victim) }\end{array}$ & $79.3 \%$ & $24.1 \%$ \\
\hline Online offers of work were given & $75.9 \%$ & $6.9 \%$ \\
\hline Parents sold victim & $75.9 \%$ & $3.4 \%$ \\
\hline Victim was escaping sexual abuse & $75.9 \%$ & $24.1 \%$ \\
\hline
\end{tabular}


Recruiter offered parents a better life for $72.4 \%$

$10.3 \%$

victim

Chaperones told parents that they would $72.4 \%$

$17.2 \%$

provide transport to victim

Pimp enticed victim

Victim was caught in cycle of exploitation

Coyote(human smugglers) enticed victim

Kidnaped victim

Victim was blackmailed

Drug Traffickers enticed victim

Victim was an addict

Boyfriend/Girlfriend enticed victim

Victim was escaping conflict or war

Victim was escaping parent's substance abuse

\begin{tabular}{ll}
$69 \%$ & $24.1 \%$ \\
$69 \%$ & $10.3 \%$ \\
$65.5 \%$ & $37.9 \%$ \\
$65.5 \%$ & $10.3 \%$ \\
$58.6 \%$ & $10.3 \%$ \\
$51.7 \%$ & $6.9 \%$ \\
$51.7 \%$ & $10.3 \%$ \\
$44.8 \%$ & $6.9 \%$ \\
$44.8 \%$ & $10.3 \%$ \\
$17.2 \%$ & $10.30 \%$ \\
\hline
\end{tabular}

According to the organizations, the demographics of those being trafficked were often or very often male $(20.6 \%)$, female $(86.2 \%)$, adults $(37.9 \%)$, children $(82.7 \%)$, youth $(82.8 \%)$, trafficked for labor $(41.4 \%)$, and trafficked for sex $(75.9 \%)$.

The organizations rated the likelihood victims who were labor trafficked would be working in particular occupations on a scale from $1=$ never, $2=$ rarely, $3=$ sometimes, $4=$ often, and $5=$ very often.

Table 3. Likelihood of labor-trafficking victims to be working in occupations

\begin{tabular}{ll}
\hline Occupation & Mean score \\
\hline Domestic worker/nanny & 3.35 \\
Mining & 3.28 \\
Peddler of goods & 2.86 \\
Restaurant worker & 2.86 \\
Beggar & 2.76 \\
Agriculture & 2.52 \\
Drug mule & 2.28 \\
Market worker & 2.10 \\
Factory worker & 2.07 \\
Hospitality/tourism & 1.90 \\
\hline
\end{tabular}


Pick pocket

Child soldier

Logging

The organizations believed that those trafficked for the purposes of labor are exploited on average 7-12 month with some being exploited for longer than 5 years.

The organizations rated the likelihood victims who were sex trafficked would be working in particular occupations on a scale from $1=$ never, $2=$ rarely, $3=$ sometimes, $4=$ often, and $5=$ very often.

Table 4. Likelihood of sex-trafficking victims to be working in particular occupations

\begin{tabular}{ll}
\hline Occupation & Mean score \\
\hline Street prostitutes & 4.25 \\
Brothel prostitutes & 3.97 \\
Sex tourism & 3.38 \\
Pornography & 2.62 \\
Live or internet shows & 1.66 \\
Mail order brides & 1.55 \\
Massage parlors & 1.55 \\
\hline
\end{tabular}

The organizations believed that those who had been sex trafficked would be exploited on average one to two years with some being exploited for over five years.

\section{Discussion}

\subsection{General Overview}

Organizations. The organizations visited were diverse in the scope of service each provided, with most being a "jack of all trades". The most commonly provided services were community advocacy and outreach and legal services, which are fundamental to prevention and intervention on human trafficking. However, the least provided services were shelter and employment services, which are necessary to sustain and treat its victims (Clawson, 2008).

Victim/Survivor Demographics. Over $80 \%$ of victims are female and $80 \%$ are children or youth, which closely reflects the Peruvian Public Ministry's Human Trafficking Strategic Information System's (SISTRA) 2013 statistics. It is interesting to note that the majority of organizations tended to focus their attention on the trafficking of females and children for the purposes of sex ( $75 \%$ of victims). This is despite the widely recognized evidence of trafficking of adult males in labor-intensive industries, such as logging and the large informal and illegal mining operations in southeast regions of the country (Jaris, 2014). It is possible 
the high numbers of reported females and children reflect a particular cultural perspective, where it is more understandable and acceptable to perceive those groups as victims, as opposed to adult males. In its gender analysis section of the 2014 report on regional trafficking in Peru, CHS noted that, "We can infer from the statistics that the majority of victims are young women and that the most common end is sexual exploitation. However, we find that the statistical analysis could be misleading by omitting from the equation other possible ends of trafficking" (CHS, 2014).

One of the alternative ends often left out of the equation is trafficking for the purposes of labor. There is very little existing research concerning the extent and severity of labor trafficking in Peru, but the government has recognized there is a problem, especially for children. According to the 2012-2021 National Strategy to Prevent and Eradicate Child Labor in Peru, of approximate 1.65 million of 7.1 million children (33.9\%), between the ages of 6 and 17 years, work in considerably dangerous jobs for 36 hours or more per week (Trabajo Infantíl, 2012) and the rates of child labor are significantly higher in the mountain (Cusco) and jungle regions (Iquitos and Madre de Dios) of Peru as compared to the Coastal regions (Lima). (Trabajo Infantile, 2012).

When asked about the most common type of labor performed by trafficked victims, respondents reported that over $41 \%$ of individuals were likely trafficked for labor, indicating mining and domestic work as the most common types. The length of exploitation for victims of labor trafficking ranges from 7-12 months to sometimes greater than five years. While the assumption for this large disparity would be that different industries have varied lengths of exploitation, this topic requires further research.

The most frequently occurring occupations for sex trafficking victims were: street prostitutes, brothel prostitutes, and sex tourism. The reported duration of exploitation for victims of sex trafficking is one to two years with some greater than five years.

There is no doubt that poverty is one of the main driving factors involved in increasing the vulnerability of populations to human trafficking. According to the latest national census data, $39.3 \%$ of Peru's population lives in poverty, $13.7 \%$ of which is in extreme poverty (Census 2007). Though almost half of the reported victims came from extreme poverty $(48.3 \%)$, it was not the only contributing factor of trafficking. The other highest reported contributing factor for the victims falling prey to trafficking was enticement by false offers of work (51.7\%), further suggesting limited resources and poverty as the primary factors contributing to vulnerability. Indeed, according to census data, $40.7 \%$ of households in Peru have at least one of five identified basic needs unmet (i.e. access to adequate shelter, sanitation services, education, and economic dependence). In most of the areas visited in this study, the percentages of unmet household needs were even higher, and respectively for Loreto (Iquitos, Jungle, 64.7\%,), Madre de Dios (Jungle, 53.4\%), Cusco (Mountains,49.6\%), and Lima (Capitol, 25.5\%) (Census Peru, 2007).

\subsection{Discoveries}

Some interesting discoveries came from this research. The historic Padrino system, whereby wealthy landowners offer to care for and educate the children of poor families in exchange for domestic service, is no longer operating as some people believe it does. In Peru, $79.3 \%$ of 
respondents had thought that the Padrino system was a predominant factor in entrapping human trafficking victims, however, it was only occurring less than a quarter of the time (24.1\%). Therefore, outreach efforts that instruct parents of the dangers of the Padrino system as their primary focus may be missing opportunities to teach parents the greater danger of being wary of offers of work to their children and youth, which entrap over half of the victims $(51.7 \%)$.

In general, it seems that recruiters were adept at enticing victims (heard: $96.6 \%$ seen: $41.4 \%$ ). The Peruvian government and research respondents perceive trafficker recruitment of victims to be very common, as evidenced by the awareness campaigns throughout the country warning of false job boards. In a CHS study of the Peruvian public's perception of human trafficking, $47.5 \%$ of Peruvians believe unemployment or a need for work to be the leading condition for vulnerability of victims (CHS Perception, 2013)..

Additionally, stakeholders often heard of other ways traffickers gained access to exploit victims, which were less substantiated by their reported frequency of occurrence. Nearly three quarters $(72.4 \%)$ of respondents said they had heard of parents being offered better lives for their children by recruiters, but only $10.3 \%$ had cases involving the ploy. Over three quarters $(75.9 \%)$ had heard of parents selling their children but only $3.4 \%$ had actually seen evidence of this method of entrapment used. Belief in parental complicity in the trafficking on youth is not uncommon in Peru (CHS Perception, 2013). The local media commonly reports sensationalistic stories about parental complicity in the trafficking or selling of their own children, which undermines effective partnerships between families who have experienced a family member being trafficked and governmental and non-governmental anti-trafficking organizations.

Other surprising discoveries were found in the way that traffickers maintained control over their victims. Often anecdotally explained methods of control such as forced drug addiction of victim (Heard: $79.3 \%$ seen: $10.3 \%$ ), shame of victim returning home (heard: $75.9 \%$ seen: 13.8\%), blackmailed victim (heard: $72.4 \%$ seen: $20.7 \%$ ), imprisoned or locked up victim (heard: $75.9 \%$ seen: $24.1 \%$ ) were perceived to be occurring with much higher frequency than the actual reported numbers suggest. However, the methods of control observed to be actually happening more frequently were: documents were taken from victim (heard $86.2 \%$ seen $51.7 \%$ ), threats of violence against victim (heard $89.7 \%$ seen $58.6 \%$ ), perpetrators held the victim's money (heard $96.6 \%$ seen $51.7 \%$ ) and isolating the victim (heard $93.1 \%$ seen $44.8 \%$ ). Taking what belonged to the victim: documents, health, money, and freedom were the true methods of control.

Another interesting finding is the perspective of some Peruvians when distinguishing labor trafficking victims from informal laborers, a distinction that potentially redefines large groups of victims as legitimate workers. In Peru, $68.6 \%$ of the non-agricultural economy functions as informal, which allows for the conditions of labor exploitation to flourish and makes it difficult for vulnerable populations to seek legal protection (ILO 2014). An estimated 19.4\% $(1,014,688)$ of children between the ages of 6-14 are working in Peru (USDOL 2014]).

\subsection{Preventing Human Trafficking: Cultural and Educational Recommendations}

One of the identified challenges is that national and local awareness campaigns are informed 
by common public perceptions readily reported by the media. It is recommended that future prevention efforts be informed by the research. Based on the existing research and the results of this study, prevention efforts should focus on education and capacity building of poor, unemployed, less educated, and marginalized individuals. Primarily this should be two-fold: 1. educating families of the dangers of work offers that seem to good to be true are not real offers and 2. educating parents and youth of the benefits of staying in school and remaining in their communities. Areas where exploitation of victims are highest often coincide where indigenous peoples live in greater numbers (Cusco, mountain region, Iquitos, jungle region). Thus organizations need to customize their prevention efforts to both be culturally sensitive to indigenous populations and to have prevention and intervention programs given in indigenous languages. One organization visited, Yanapanakusan, in Cusco, transmitted radio broadcasts about trafficking prevention in Quechua. This was a particularly great medium of transmitting information since they were able to give information to people in their native language that often did not have access to formal education or television programming.

In Peru there are some societal changes, if put in place could have long lasting effects for all Peruvians. The first is to focus on poverty reduction and jobs creation. Human trafficking is symptomatic of the general lack of sustained, inclusive and sustainable economic growth in the global economy, in developing economies in particular. Slow and jobless growth, a shift to informal modes of production and increasing reliance on part-time and temporary workers are all trends that have contributed to trafficking-vulnerable populations.

A second recommendation is to focus on making education more affordable and available for all Peruvians and improving upon the relatively high truancy rates. Educating females, in particular, can help decrease vulnerability, as it has long since been understood in developmental circles as the best way to move a country out of poverty since females will continue to educate their children (UNFPA, 2005). It also would be worth investigating incentive based programs for parents whose children stay in school and graduate.

Additionally, it is hoped that the many organizations visited can increase their efforts to support each other and the flow of information, knowledge, and capacity building. The greater communication, and sharing of information between organizations increases the success of eradicating human trafficking in Peru. Similarly, greater knowledge of each other's activities helps to construct a more dense patchwork of programs and referral networks.

\subsection{Protecting Survivors of Human Trafficking: Clinical and Advocacy Recommendations}

According to the Department of State's Trafficking in Persons Report for Peru, the Peruvian government provided inadequate services to trafficking victims and failed to dedicate funding for specialized care (2014). Our research concurs with the DOS' findings and there are many recommendations that can be made from the research (DOS, 2014). First, there needs to be a concerted effort to support parents to advocate for their children and youth to stay in their own communities and continue to attend school. Additionally, families, especially poor families, need to be educated about human trafficking and red flags of when to be concerned about the possibility of trafficking. Children and youth need to be educated that if offers of work are too good to be true they are not valid offers. Parents, children and youth need to be educated of how important documents are and not to allow anyone to take documents from children and youth. It is important that organizations work with and support parents of 
trafficked children and youth rather than vilify and dehumanize them as monsters who do not love their children.

Finally, due to their length of exploitation, most victims will take years to heal under the care of a mental health specialist with a trauma focus. Supporting victims holistically, including their physical, emotional, spiritual, legal, educational and vocational needs will take a well-coordinated team working together over the long run with the necessary resources in place. Anecdotal evidence was clear that cases can take as long as 6-7 years before a victim testifies in court. Thus, it is incredibly important that survivors are provided ongoing services in the interim, to rebuild their lives and avoid recidivism into exploitation.

\subsection{Prosecuting Human Traffickers: Policy Recommendations}

The current law (Article 153 of Peruvian Law 28950 of the Penal Code) defines human trafficking and criminalizes it. However, it is very infrequently used to prosecute traffickers and both our anecdotal evidence and the U.S. State Department have noted that the Government of Peru has made uneven efforts to investigate and prosecute trafficking offenses. The government's own ombudsman's office reported that judges often failed to sentence traffickers for aggravated trafficking in cases involving child victims, and official complicity is a concern (TIP, 2014). We often heard that human traffickers were charged under lesser crimes which were easier to prosecute and carry less harsh punishments (e.g. pimping). This indicates that lawyers and judges need significant training and education in order to prosecute more cases to the full extent of the law. Police and investigators commonly conflate prostitution and sex trafficking, leading to unreliable data. Thus, it is important that law enforcement be trained on how to identifying and appropriately working with victims of human trafficking.

\section{Limitations}

The scope of this research was relatively small, with 30 organizations interviewed, and it is reasonable to assume some voices were lost. However, we were able to speak with people who work with victims from all of the departments of Peru and were able to visit the four areas most associated with human trafficking in Peru: Loreto, Madre de Dios, Cusco, and Lima.

\section{Future Research}

We would like to continue researching human trafficking in Peru by studying the efficacy of current and future prevention, intervention and treatment programs in Peru. Additionally, we would like to separate the prevention, intervention and treatment programs by regions to see variations and differences within and between regions.

\section{References}

Bowser, F. P. (1974). The African slave in colonial Peru (pp. 1524-1650). Stanford, California: Stanford University Press.

Brennan, D. (2005). Methodological Challenges in Research with Trafficked Persons: Tales from the Field. International Organization on Migration, Data and Research on Human Trafficking: a Global Survey. Retrieved March 20, 2015, from http://www.iom.int/jahia/webdav/site/myjahiasite/shared/shared/mainsite/published_docs/boo ks/data_res_human.pdf 
Capital Humano y Social Alternativo. (2010). La Trata de Personas en El Peru (2nd ed.). Lima: Peru: Publimagen ABC.

Capital Humano y Social Alternativo. (2013). Trata de Personas en el Perú: La agenda pendiente 2013-2016. Lima: Peru: Publimagen ABC.

Capital Humano y Social Alternativo. ¿Qué Pasa en las Regiones del Perú? Trata de Personas: Similtudes y Divergencias (2014). Lima: Peru: Publimagen ABC.

Capital Humano y Social Alternativo. (2013). Percepción y realidad: ¿hay trata de personas en el Perú? Lima: Peru: SINCOeditores SAC.

Clawson, H. J., \& Dutch, N. B. A. (2008). Addressing the Needs of Victims of Human Trafficking: Challenges, Barrier, and Promising Practices. U.S. Department of Health and Human Services. Retrieved May 6, 2015, from http://aspe.hhs.gov/hsp/07/humantrafficking/needs/ib.pdf

Central Intelligence Agency World Factbook. Peru. Retrieved April 12, 2015, from https://www.cia.gov/library/publications/the-world-factbook/geos/pe.html

El Comercio. Search for "trata de personas." Retrieved April 22, 2015, from http://elcomercio.pe/noticias/trata-personas-516657

Free the Slaves. About Slavery: Slavery Today. Retrieved April 22, 2015, from http://www.freetheslaves.net/about-slavery/slavery-today/

Government of Peru. Estrategia Naciona para la Prevención y Erradicación del Trabajo Infantíl 2012-2021. Lima; 2012.

Haynes, D. F. (2004). Used, Abused, Arrested and Deported: Extending Immigration Benefitsto Protect the Victims of Trafficking and to Secure the Prosecution of Traffickers. Human Rights Quarterly, 26(2), 221-272. http://dx.doi.org/10.1353/hrq.2004.0021

Instituto Nacional de Estadistica e Informatica. Censos Nacionales Mapas. (2007). Lima, Peru. Retrieved April 20, 2015, from http://censos.inei.gob.pe/Censos2007/Pobreza/

International Labour Organization. Trends in Informal Employment in Peru 2004-2012. (2014). Retrieved June, 11, 2014, from http://webcache.googleusercontent.com/search?q=cache:p82qoD0ZpokJ:www.ilo.org/wcmsp 5/groups/public/---americas/---ro-lima/documents/publication/wcms_245891.pdf $+\& c d=1 \&$ hl $=\mathrm{en} \& \mathrm{ct}=\mathrm{clnk} \& \mathrm{gl}=\mathrm{us}$

Ministerio Público. Systema de Información Estratégica Sobre Trata de Personas (SISTA). (2013). Lima, Peru. from http://www.mpfn.gob.pe/escuela/contenido/actividades/docs/2747_09_sistema_sistra_observ atorio.pdf

Mujica, Jaris. Elementos Comparados del Impacto de la Trata de Personas en la salud de víctimas adolescentes en el contexto de la minería ilegal de oro en Madre de Dios. PROMSEX. Lettera Gráfica S.A.C. 2014.

Mujica, Jaris. Elementos Comparados del Impacto de la Trata de Personas en la Salud de Víctimas adolescentes en el contexto de la minería ilegal de oro en Madre de Dios. (2014). Lima, Peru: Lettera Gráfica.

Stern, S. J. (2005). The Tragedy of Success. The Peru Reader (2nd ed, pp. 124-148.). Durham, 


\section{Macrothink \\ International Journal of Social Work \\ ISSN 2332-7278 \\ 2016, Vol. 3, No. 1}

North Carolina: Duke University Press,

United Nations Children's Fund. Rechaza Uso de Niños, Niñas y Adolecentes en Acciones de $\begin{array}{lllll}\text { Violencia. } & \text { Retrieved } & \text { November } & 15, & 2012,\end{array}$ http://www.unicef.org/peru/spanish/UNICEF_rechaza_uso_de_ninos.pdf

United Nations Population Fund (UNFPA). Strategic Investments: The Equality Dividend. (2005). Retrieved July 30, 2015 from http://www.unfpa.org/sites/default/files/pub-pdf/swp05_eng.pdf

United Nations News Centre, Human trafficking has no place in modern world, General Assembly President says. (2014, July 14). Retrieved April 22, 2015, from http://www.un.org/apps/news/story.asp?NewsID=48271

United States Department of Health and Human Services. Quick Facts. Retrieved April 22, 2015, from http://www.acf.hhs.gov/programs/endtrafficking/quick-fact

U.S. Department of Labor. (2014). Findings on the Worst Forms of Child Labor in Peru. (2014). Retrieved from http://webcache.googleusercontent.com/search?q=cache:jWG1uHfVb-UJ:https://www.dol.go $\mathrm{v} / \mathrm{ilab} /$ reports/child-labor/findings/2014TDA/peru.pdf $+\& \mathrm{~cd}=1 \& \mathrm{hl}=\mathrm{en} \& \mathrm{ct}=\mathrm{clnk} \& \mathrm{gl}=\mathrm{us} \& \mathrm{clien}$ $\mathrm{t}=$ safari

United States Department of State. (2014). Trafficking in Persons Report. Washington, D.C. Valdéz, C. R. (2012). The RETA System and Human Trafficking: The History of a Registry, the Registry of a History. Lima, Peru: Ecoprint.

Valdéz, C. R. (2012). CHS Alternativo. Interview by Chris Huey. Lima, Peru.

Walk Free Foundation. Global Slavery Index. Retrieved April 20, 2015, from http://www.globalslaveryindex.org/country/peru/

Zevallos, Oscar Guadalupe. Asociación Huarayo. In-person interview by Chris Huey. June 11, 2014. Puerto Maldonado, Peru.

\section{Copyright Disclaimer}

Copyright reserved by the author(s).

This article is an open-access article distributed under the terms and conditions of the Creative Commons Attribution license (http://creativecommons.org/licenses/by/3.0/). 